\title{
Multicentre Epidemiology and Survival Study of B Cell Non Hodgkin Lymphoma Patients In Indonesia
}

\section{Ary Harryanto Reksodiputro*}

Indonesian Lymphoma Study Group, The Indonesian Society of Haematology Medical Oncology, Indonesia

*Corresponding author: Ary Harryanto Reksodiputro, Indonesian Lymphoma Study Group, The Indonesian Society of Haematology Medical Oncology, Indonesia, Tel: 0628161877583; E-mail: perhompedin@yahoo.com, arryrek@gmail.com

Received date: Oct 16, 2014, Accepted date: Mar 12, 2015, Publication date: Mar 18, 2015

Copyright: ( 2015 Reksodiputro $\mathrm{AH}$. This is an open-access article distributed under the terms of the Creative Commons Attribution License, which permits unrestricted use, distribution, and reproduction in any medium, provided the original author and source are credited.

\begin{abstract}
Aim: To get a national epidemiology data of B Cell Non Hodgkin Lymphoma (NHL) patients in Indonesia, including: demographic and clinical characteristics, histological type and survival time.

Methods: The study was multicentre cross sectional study on patients diagnosed as B Cell Non Hodgkin Lymphoma from 13 haematology centres in Indonesia, from November 2008 until July 2010.

Result: One hundred and sixty four B Cell Non Hodgkin Lymphoma patients whom were collected had median age of 51 years old with the most histological type of Diffuse Large B Cell Lymphoma (DLBCL). Most of the patients was male $(55.5 \%)$, stage II of disease (35.4\%) with ECOG performance status score of $0-1(77.7 \%)$. They had chief complaint of weight loss $(44.7 \%)$ and tumour of the neck $(54.1 \%)$. A complete response was achieved in $67.9 \%$ patients who continue for treatment at Dharmais Cancer Centre Hospital with 36 months survival rate was $36.4 \%$ and median survival time of 8 months $(95 \% \mathrm{Cl}$ was $2.042-13.958)$
\end{abstract}

Conclusion: Among B Cell NHL patients in this study, the most common characteristics was: male, median age of 51 years old, stage II of the disease, ECOG performance status score of $0-1$ and DLBCL type as the common type. The 36 months survival rate was $36.4 \%$ with median survival time of 8 months.

Keywords: Lymphoma; Epidemiology; Survival

\section{Introduction}

Malignant lymphoma is neoplasia derived from lymphoid cells. The various types of Non Hodgkin Lymphomas (NHL) represent neoplastic lymphoid cells arrested at different stage of normal differentiation [1-4]. The incidence of NHL had been increasing in western country and more pronounced in whites, male and elderly $[5,6]$. In Indonesia, based on statistic data from Dharmais Cancer Centre Hospital, 2006, it was reported that Non Hodgkin Lympoma was the tenth most common diagnosed cancer. So far there is no national epidemiology data about Non Hodgkin Lymphoma patients in Indonesia.

Diffuse Large B cell lymphoma (DLBCL), the first most common lymphoma, comprising $30 \%$ of the whole B cell lymphomas [2]. As the most common subtype, DLBCL has a heterogeneous clinical characteristics in which $40 \%$ of patients have good response and prolonged survival to current therapy whereas the remainder succumb to the disease [7]. DLBCL encompasses several unique malignant lymphoid disease and had different features of clinical behavior, morphology, immunology and molecular phenotype that can affect the treatment and prognosis of the disease $[1,2]$. There is diversity in gene expression among the tumors in DLBCL, apparently reflecting variation of the tumor proliferation rate, host response and differentiation state of the tumor. Patients with germinal centre B-like DLBCL have a significantly better overall survival than those with activated B-like DLBCL [7].
The aim of this study is to get a national epidemiology data of B Cell NHL patients in Indonesia, including: demographic characteristics, clinical characteristics, histological type and survival, hence enabling us to make a standard treatment protocol for our patients.

\section{Methods}

A multicentre cross sectional study on patients diagnosed as Non Hodgkin Lymphoma (NHL) was done. The case recruitment were initiated from the clinicians from 13 haematology center in Indonesia who selected and included the cases with complete data. The data submitted consisted of: NHL histological diagnosis, patient characteristics, clinical characteristics, type of treatment, International Prognostic Index (IPI) score and also the treatment response. The histopathological review was done in each center based on morphology and immunostaining.

Each pathologist in the center received the case accession number from their clinician counterpart for case retrieving and reviewing. A referral system were applied for pathology review. Cases that need to be confirmed with more complete antibody panel for subtyping were sent to the referral pathology centers. Based on regional area and the facilities available, three levels of referral system were established as follows: the $1^{\text {st }}$ line centers will refer the specimen to the $2^{\text {nd }}$ line centers for $\mathrm{B} / \mathrm{T}$ subtyping. The $2^{\text {nd }}$ line centers referred their own specimen as well as the referring specimen need to be subtyped or confirmed using more complete antibody panel to the 3rd line center (Cipto Mangunkusumo hospital). The $3^{\text {rd }}$ line center review its own and the referred specimen for subtyping. Finally the $3 \mathrm{r}^{\mathrm{d}}$ line center 
Page 2 of 5

reviewed all cases reported from all centers. The antibodies used were CD20, CD3, CD79a, CD43, CD5, cyclin D1, CD23, CD21, CD10, BCL2, BCL6, kappa, lambda , TDT, CD15, CD30, CD38, CD138, CD68, AE1/AE3, LCA, HMB45, Vimentin and the standard streptavidin biotin staining procedure was employed using automated immunostainer at the 3rd line center and manually at the 2nd line centers.

Treatment responsewere analyzed in group of patients who got four cycles or more of chemotherapy regimen with radiotherapy combination or chemotherapy alone. Estimation of the survival analysis were calculated according to Kaplan Meier product limit method.

We also reported about 50 consecutive patients who were diagnosed as B Cell NHL and treated at the Dharmais Cancer Centre Hospital, Jakarta, Indonesia, one of our hematology centre which was included in this multicentre study. Among these fifty patients, we also reported about survival of DLBCL patients who were treated at this Dharmais Cancer Centre Hospital.

\section{Results}

Two hundred consecutive Non Hodgkin Lymphoma cases were found from November 2008 until July 2010. Among the 200 patients, 164 patients were diagnosed as B Cell NHL. Fifty five percent of the patients were male with a median of age was 51 years old. Based on educational background data, most of the patients had a senior high school background (31.4\%) and only about $18.9 \%$ finished college (Tables 1 and 2).

\begin{tabular}{|l|l|l|}
\hline Haematology Centre & Frequency number & Percentage \\
\hline Jakarta & 114 & 57 \\
\hline Palembang & 28 & 14 \\
\hline Bandung & 16 & 8 \\
\hline Manado & 4 & 2 \\
\hline Yogyakarta & 4 & 2 \\
\hline Semarang & 2 & 1 \\
\hline Malang & 7 & 3.5 \\
\hline Banjarmasin & 6 & 3 \\
\hline Surabaya & 4 & 2 \\
\hline Solo & 3 & 1.5 \\
\hline Makasar & 1 & 0.5 \\
\hline Bali & 8 & 4 \\
\hline Medan & 3 & 1.5 \\
\hline
\end{tabular}

Table 1: Haematology centre in Indonesian epidemiology study of NHL.

\begin{tabular}{|c|c|c|c|c|c|c|}
\hline No & Characteristic & $\begin{array}{l}\text { Frequen } \\
\text { cy }\end{array}$ & $\%$ & $\begin{array}{l}\text { Media } \\
\mathrm{n}\end{array}$ & SD & $95 \% \mathrm{Cl}$ \\
\hline \multirow[t]{2}{*}{1} & Sex & & & & & \\
\hline & Male & 91 & 55.5 & & & \\
\hline
\end{tabular}

\begin{tabular}{|c|c|c|c|c|c|c|}
\hline & Female & 73 & 44.5 & & & \\
\hline 2 & Age at diagnosis & & & 51.00 & 14.615 & $\begin{array}{l}46.72-5 \\
1.26\end{array}$ \\
\hline \multirow[t]{7}{*}{3} & Group of Age & & & & & \\
\hline & $<20$ years & 6 & 3.7 & & & \\
\hline & $20-29$ years & 12 & 9.2 & & & \\
\hline & $30-39$ years & 26 & 14.1 & & & \\
\hline & $40-49$ years & 32 & 20.2 & & & \\
\hline & $50-59$ years & 46 & 28.2 & & & \\
\hline & $\geq 60$ years & 41 & 24.5 & & & \\
\hline \multirow[t]{6}{*}{4} & Race & & & & & \\
\hline & Javanese, Sundanese & 102 & 63.4 & & & \\
\hline & Batak, Padang, Malay & 27 & 16.8 & & & \\
\hline & Betawi & 7 & 4.3 & & & \\
\hline & Banjar & 7 & 4.3 & & & \\
\hline & Others & 18 & 11.2 & & & \\
\hline \multirow[t]{6}{*}{5} & Educational Background & & & & & \\
\hline & None & 3 & 1.9 & & & \\
\hline & Elementary School & 54 & 34 & & & \\
\hline & Junior High School & 22 & 13.8 & & & \\
\hline & Senior High School & 50 & 31.4 & & & \\
\hline & College/University & 30 & 18.9 & & & \\
\hline \multirow[t]{6}{*}{6} & Ocupational types & & & & & \\
\hline & Farmer, holticulture & 24 & 15.2 & & & \\
\hline & Employee, Labour & 31 & 19.7 & & & \\
\hline & Housewive & 47 & 29.9 & & & \\
\hline & Civil servant, army, police & 26 & 16.5 & & & \\
\hline & Others & 29 & 18.4 & & & \\
\hline \multirow[t]{5}{*}{7} & Exposure & & & & & \\
\hline & Manure & 19 & 11.9 & & & \\
\hline & Chemical stuff & 15 & 9.4 & & & \\
\hline & Cigarette & 37 & 23.3 & & & \\
\hline & Ultraviolet & 22 & 13.8 & & & \\
\hline
\end{tabular}

Table 2: Patient characteristics of Indonesian B Cell NHL patients $(\mathrm{N}=164)$.

Forty-two percent patients got some exposure prior to the disease. Based on type of exposure, most had exposure to cigarette (23.3\%), ultraviolet (13.8\%) and manure (11.9\%). According to the study, most of the patients had weight loss (44.7\%) and fever $(27 \%)$ as chief complaint. The neck (54.1\%) was the most common site found with 
Citation: Reksodiputro AH (2015) Multicentre Epidemiology and Survival Study of B Cell Non Hodgkin Lymphoma Patients In Indonesia. J Blood

Page 3 of 5

two other most common locations were: inguinal (18.9\%) and abdominal nodes (18.1\%). Comorbid diseases found were: hypertension (12.5\%), diabetes melitus (6.3\%) and tuberculosis $(5.6 \%)$ (Table 3).

\begin{tabular}{|c|c|c|c|}
\hline No. & Characteristic & Frequency & $\%$ \\
\hline \multirow[t]{5}{*}{1} & \multicolumn{3}{|l|}{ Symptoms (N=159) } \\
\hline & Fever & 43 & 27 \\
\hline & Weight loss & 71 & 44.7 \\
\hline & Pain & 30 & 18.8 \\
\hline & Others & 36 & 22.7 \\
\hline \multirow[t]{5}{*}{2} & \multicolumn{3}{|l|}{ Comorbid disease $(\mathrm{N}=160)$} \\
\hline & Hypertension, heart disease & 26 & 16.2 \\
\hline & Diabetes Melitus & 10 & 6.3 \\
\hline & Tuberculosis & 9 & 5.6 \\
\hline & $\begin{array}{l}\text { Others (asthma, stroke, cancer, } \\
\text { hepatitis) }\end{array}$ & 18 & 11.2 \\
\hline \multirow[t]{6}{*}{3} & \multicolumn{3}{|l|}{ Tumor location $(\mathrm{N}=159)$} \\
\hline & Neck & 86 & 54.1 \\
\hline & Axilla & 19 & 11.9 \\
\hline & Abdomen & 29 & 18.2 \\
\hline & Inguinal & 30 & 18.9 \\
\hline & Others & 53 & 33.3 \\
\hline \multirow[t]{3}{*}{4} & \multicolumn{3}{|l|}{ Waldeyer involvement $(\mathrm{N}=157)$} \\
\hline & Yes & 26 & 16.6 \\
\hline & No & 131 & 83.4 \\
\hline \multirow[t]{5}{*}{6} & \multicolumn{3}{|l|}{ Stage of diasease $(N=144)$} \\
\hline & I, IE & 40 & 27.8 \\
\hline & II, IIE & 51 & 35.4 \\
\hline & III, IIIE, IIIES & 40 & 27.8 \\
\hline & IV, IVE & 13 & 9.0 \\
\hline \multirow[t]{6}{*}{7} & \multicolumn{3}{|c|}{ ECOG Performance Status Score $(\mathrm{N}=164)$} \\
\hline & 0 & 57 & 38.5 \\
\hline & 1 & 58 & 39.2 \\
\hline & 2 & 20 & 13.5 \\
\hline & 3 & 11 & 7.4 \\
\hline & 4 & 2 & 1.4 \\
\hline
\end{tabular}

Table 3: Clinal characteristics of Indonesian B Cell NHL patient.

About $35 \%$ of patients had stage II, $28 \%$ of patients were at stage I and about $27 \%$ of patients were at stage III and only about $9 \%$ of patients had stage IV. Only $1.4 \%$ patients had ECOG score 4, while
77.7\% had ECOG score of 0 or 1. Based on histologycal types of B Cell Non Hodgkin Lymphoma, we found that $68.2 \%$ of Indonesian NHL patients were Diffuse Large B Cell Lymphoma (DLBCL) (Table 4).

\begin{tabular}{|l|l|l|l|}
\hline No. & Characteristic & Frequency & $\%$ \\
\hline 1 & Diffuse Large B Cell Lymphoma & 116 & 68.2 \\
\hline 2 & Follicular lymphoma & 17 & 10 \\
\hline 3 & Small Cell lymphoma & 9 & 5.3 \\
\hline 4 & $\begin{array}{l}\text { B cell lymphoma, unclassifiable with } \\
\text { feature between DLBCL and Burkitt }\end{array}$ & 4 & 2.3 \\
\hline 5 & Mantle Cell lymphoma & 3 & 1.9 \\
\hline 6 & Small lymphocytic lymphoma & 2 & 1.1 \\
\hline 7 & Burkitt limfoma & 1 & 0.6 \\
\hline 8 & Lymphoplasmacytic lymphoma & 1 & 0.6 \\
\hline 9 & MALT & 1 & 0.6 \\
\hline 10 & Marginal zone lymphoma-nodal & 1 & 0.6 \\
\hline 11 & $\begin{array}{l}\text { Unclassifiable types of Malignum } \\
\text { lymphoma }\end{array}$ & 15 & 8.8 \\
\hline
\end{tabular}

Table 4: Histological type of Indonesian B Cell NHL patients ( $\mathrm{N}=170)$.

The other most common type of NHL were: follicular lymphoma (10\%), small cell lymphoma (5.3\%) and B cell lymphoma unclassifiable between DLBCL and Burkit lymphoma (2.3\%). Eight percent of patients had unclassifiable type of malignum lymphoma.

One of our haematology centre in this study was Dharmais Cancer Centre Hospital, Jakarta. Seventy four percent of NHL patients who treated at Dharmais Cancer Centre Hospital had DLBCL type. Female (54.1\%) was the most common gender we found in this study with $45.9 \%$ patient was in the $>40-60$ years old group of age. Forty percent of this patients had weight loss as chief complaint with neck as the most common site of tumor (42\%). Based on IPI score, most of the patients had score of low intermediate risk (36\%) and low risk (32\%) (Table 5).

\begin{tabular}{|l|l|l|l|}
\hline No. & Characteristic & Frequency & $\%$ \\
\hline 1 & Age & 36 & 72 \\
\hline & $\leq 60$ years & 14 & 28 \\
\hline & $>60$ years & \multicolumn{3}{|l|}{} \\
\hline 2 & Stage of disease & 30 & 60 \\
\hline & I or II & 20 & 40 \\
\hline & III or IV & \multicolumn{2}{|l|}{} \\
\hline 3 & LDH Serum & 10 & 20 \\
\hline & Normal & 35 & 70 \\
\hline & Increase & 5 & 10 \\
\hline & No data & \multicolumn{2}{|l}{} \\
\hline 4 & ECOG PerformanceStatus & \multicolumn{3}{|l|}{} \\
\hline
\end{tabular}


Page 4 of 5

\begin{tabular}{|l|l|l|l|}
\hline & Score : 0 (ECOG 0-1) & 37 & 74 \\
\hline & Score : 1 (ECOG 2-4) & 24 & 16.6 \\
\hline 5 & Extranodal involvement & & \\
\hline & $\leq 1$ location & 50 & 100 \\
\hline & $>1$ location & 0 & 0 \\
\hline 6 & IPI Score & \multicolumn{2}{|l|}{} \\
\hline & 0 (low risk) & 6 & 12 \\
\hline & 1 (low risk) & 10 & 20 \\
\hline & 2 (low intermediate risk) & 18 & 36 \\
\hline & 3 (high intermediate risk) & 10 & 20 \\
\hline & 4 (high risk) & 1 & 2 \\
\hline & No data & 5 & 10 \\
\hline
\end{tabular}

DLBCL varied between 30 to $60 \%$ (WHO 2008). This study revealed DLBCL is slightly higher in Indonesia compared to other Asian countries. Follicular lymphoma was commonly low in Asian countries, as demonstrated in our study done in the year 2000-2002 (unpublished data) that no pure follicular lymphoma was found, but in this study we found it as the second most common subtype. Some believed that the lifestyle might have influenced this shifting pattern.

In our country, immunostaining for lymphoma cases is not a reflexive procedure due to financial reason. Only patient who can afford immunostaining will be proceed to this diagnostic modalities and only few centers are equipped with immunostaining. Cipto Mangunkusumo Hospital is the largest national hospital serving as the top referral center in Indonesia, so it is the most well equipped with immunostaining. However, genetic studies like gene rearrangement or FISH cytogenetic for lymphoma are unavailable yet. This explain the high frequency of unclassifiable case in our series as compare to studies in other countries.

Although there is a shifting pattern for follicular lymphoma, the indolent group of lymphoma (small lymphocytic lymphoma, mantle cell lymphoma, marginal zone lymphoma, lymphoplasmacytic lymphoma) remain low comparable to the eastern countries.

NHL Patients based on IPI Score.

Among of 50 patients, we reported of 36 patients (72\%) who decided to continue the treatment (chemotherapy alone or combination with radiotherapy) of which only 28 patients in the treatment group were analyzed for treatment response. A complete response was achieved in 19 patients (67.9\%), the others $10.8 \%$ achieved only partial response. Two patients died during the chemotherapy course and 4 patients were in stable or progresive disease state. Based on chemotherapy regimen that used in a complete response group, $\mathrm{CHOP}$ or $\mathrm{RCHOP}$ regimen $(68.4 \%)$ was the most chemotherapy regimen used in this study. Other regimen include: COP, DHAP or combination regimen.

Among these fifty NHL patients, only 33 patients can be evaluated about survival time. We reported 36 months overall survival rate was about $36.4 \%$ with median survival time of 8 months (95\% confidence interval : 2.042-13.958) (Figure 1).

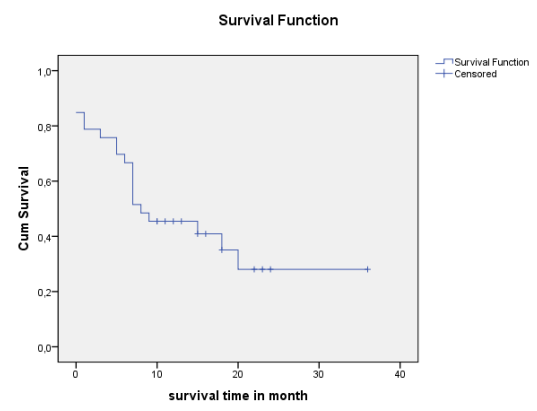

Figure 1: Kaplan-Meier Graphic of Dharmais Hospital B cell NHL patients.

\section{Discussion}

In the western countries, DLBCL and follicular lymphoma constitutes $37 \%$ and $29 \%$ respectively, while in the eastern countries,

\section{Conclusion}

We reported of Diffuse Large B Cell Lymphomas (69\%) as the most type of B Cells Non Hodgkin Lymphoma in this multicentre study which had the most group were: male (55.5\%) whith median of age of 51 years old. The most chief complaint were : weight loss $(44.7 \%)$ and fever $(27 \%)$ which had neck as the most common sites of tumour location (54.1\%). The most types of exposure that was reported was cigarette/smoke (23.3\%).

Based on type of chemoteraphy regimen that used in a complete respons group, we reported that $\mathrm{CHOP} / \mathrm{RCHOP}$ regimen (68.4\%) was the most chemotherapy regimen used in this study.

\section{Acknowledgments}

We acknowledge PT Roche Indonesia for supporting this study. We thank all the haematologist who recruited the patients and all the pathologist who examined the samples. Author would like to mention contributors that had helped through this study. Arry Harryanto Reksodiputro, Djumhana Atmakusuma, Iman Supandiman, Nusyirwan Acang, Bachtiar Fanani Lubis, I Made Bakta, Azmi S Kar, Andi Fachrudin, Ami Ashariati, C Suharti, Johan Kurnianda, Suradi Maryono, Budi Darmawan Machsoes, Mediarty Syahrir, Darwin T Prenggono, Harlinda Haroen, Ikhwan Rinaldi, Nadia A Mulansari, Resti Mulya Sari, Sri Agustini K, Toman Lumban Toruan.

Aswiyanti Asri (Andalas University), Gunawan Arsyadi (Hassanudin University), Upik Miskad (Makassar), Noor Yazid AD (Diponegoro University), PF Laihad (Sam Ratulangi University), HM Nadjib D Lubis (Sumatera Utara University), Yusuf Fantoni (Sriwijaya University, Palembang), Indrawati (Gajah Mada University. Yogyakarta), Ambar Mudigdo (Sebelas Maret University), Mujiwiyono Handaru Eko (Brawijaya University), Dyah Fauziyah (Airlangga University), Hasrayati (Padjajaran University), Betty Hernowo (Padjajaran University), Sindrawati (Surabaya Oncology Hospital), Nia Kania (Banjarmasin Hospita), Ni Wayan Winarti (Udayana University), Evlina Suzanna (Dharmais Cancer Centre Hospital), Endang SR Hardjolukito (Indonesia University). 
Citation: Reksodiputro AH (2015) Multicentre Epidemiology and Survival Study of B Cell Non Hodgkin Lymphoma Patients In Indonesia. J Blood Disorders Transf 6: 257. doi:10.4172/2155-9864.1000257

Page 5 of 5

\section{References}

1. Diebold J (2001) World Health Organization classification of malignant lymphomas. Experimental Oncology 23: 101-103.

2. http://accessmedicine.mhmedical.com/content.aspx? bookid $=371 \&$ sectionId $=41587724$

3. Gordon LI (2002) Non hodgkin lymphomas. Manual of clinical hematology (3rd edtn). Philadelpia, Lippincot William \& Wilkins.

4. Gutierrez ME, Little RF, Wilson WH (2005) Non hodgkin lymphomas. Bethesda Handbook of Clinical Oncology (2nd edtn). Philadelpia, Lippincot William \& Wilkins.
5. Mitri J, Castillo J, Pittas AG (2008) Diabetes and risk of Non-Hodgkin's lymphoma: a meta-analysis of observational studies. Diabetes Care 31: 2391-2397.

6. http://www.lymphomation.org/statistics.htm.

7. Alizadeh AA, Eisen MB, Davis RE, Ma C, Lossos IS, et al. (2000) Distinct types of diffuse large B-cell lymphoma identified by gene expression profiling.Nature 403: 503-511. 